\title{
ANALISIS FOLLOWING TO FOLLOWERS RATIO TIKTOK PADA 5 ARTIS TIKTOK DENGAN FOLLOWERS TERBANYAK
}

\author{
Vierel Qoisan Sabil Gumilar \\ vierelqoisansabilgumilar@gmail.com
}

\begin{abstract}
TikTok is a social media application launched by a Chinese company. TikTok allows users to create 15 -second videos accompanied by music, filters and some other creative features. In Indonesia there are 30.7 million users active, making Indonesia the country with the largest TikTok users in this world. The large number of active TikTok users in Indonesia can certainly provide an opportunity for Followers to make the TikTok platform a social media platform Follow. The 5 Most Followers in Indonesia who use TikTok as a Follow platforms, namely: Sandy S.S, Cahyanirynn, Ria Ricis, Harna Bhagwani, Saalhaerid The purpose of this study is to calculate the credibility of the account performance of the 5 Most Followers TikTok in Indonesia. The method used for this research is quantitative exploratory method. The results of this study indicate that the most Tiktok accounts are Ria Ricis who gets the first rank and has the most credibility for the performance of Tiktok Followers accounts.
\end{abstract}

\begin{abstract}
ABSTRAK
TikTok merupakan aplikasi sosial media yang diluncurkan oleh perusahaan asal Tiongkok.TikTok memungkinkan penggunanya membuat video berdurasi 15 detik yang disertai dengan musik, filter, dan beberapa fitur kreatif lainnya. Di Indonesia terdapat 30,7 juta pengguna yang aktif sehingga menjadikan Indonesia sebagai negara dengan pengguna TikTok terbesar di dunia. Maraknya jumlah pengguna TikTok yang aktif di Indonesia tentu dapat memberikan peluang bagi Followers untuk menjadikan platform TikTok sebagai platform social media Follow. Adapun 5 Followers Terbanyak Di Indonesia yang memanfaatkan TikTok sebagai platform Follow, yaitu : Sandy S.S, Cahyanirynn, Ria Ricis, Harna Bhagwani, Saalhaerid Tujuan dari penelitian ini yaitu untuk menghitung kredibilitas dari performa akun TikTok 5 Followers Terbanyak Di Indonesia . Metode yang digunakan untuk penelitian ini yaitu metode eksploratif kuantitatif. Hasil dari penelitian ini menunjukan bahwa akun tiktok terbanyak adalah Ria Ricis mendapatkan peringkat pertama dan memiliki kredibilitas performa akun Tiktok Followers terbanyak.
\end{abstract}

Keyword : Credibility Account TikTok ; Social Media Marketing ; Social Media TikTok ; Following To Followers Ratio ; Artis Tiktok. 


\section{PENDAHULUAN}

Pada era saat ini, Teknologi data berkembang terus menjadi mutahir dari tahun ke tahun. Pertumbuhan teknologi ini sudah menimbulkan pergantian dalam kehidupan masyarakat di berbagai bidang. Selain itu, perkembangan teknologi banyak memberikan manfaat positif bagi kehidupan warga. Seiring dengan pergantian era, inovasi teknologi terus menjadi bermacam- macam. Terlebih dengan meningkatnya kebutuhan hendak internet sebagai sarana untuk pertukaran dan penyebaran informasi secara cepat dan murah. Menurut data dari Electronic Marketing Research Institute, pengguna internet di negeri Indonesia terus meningkat tiap tahun.

Saat ini salah satu media baru yang saat ini sedang populer dan diminati oleh segala kalangan mulai dari anak kecil sampai orang tua adalah Tik Tok. Tik Tok adalah salah satu platform media yang berasal dari Republik Rakyat Tiongkok tempat di mana penggunanya dapat membagikan sebuah video yang awalnya berdurasi 15 detik dan sekarang bisa mencapai 3 menit. Untuk saat ini, aplikasi ini lebih banyak digunakan sebagai media untuk mengekspresikan diri oleh penggunanya yang dapat dilihat dari konten-konten yang menarik perhatian seperti berjoget diiringi sebuah lagu dan konten-konten kreatifitas lainnya. Aplikasi video sosial ByteDance TikTok mencapai lebih dari 2 millyar unduhan dan meraup hampir \$3 millyar secara global - lebih dari lima kali lipat pendapatannya pada 2018 -2019 (No Title $\square \square \square \square \square \square \square$, n.d.) Dalam survei di penghujung 2019 tersebut, bisa dikatakan bahwa Tik Tok menjadi salah satu aplikasi yang saat ini sedang populer dari tahun-tahun sebelumnya.

Selebritas (bahasa Inggris: Celebrity) adalah orang terkenal lantaran terlalu dekatnya dengan dunia pemberitaan (pers). Setiap gerak langkahnya, selebritas tak pernah luput dari sorotan media massa. Ada sebagian selebritas menjadi populer karena prestasi dan kiprahnya, ada pula selebritas yang populer karena kontroversi kehidupannya. Karier yang sukses dalam bidang olahraga dan hiburan juga berkaitan dengan status sebagai selebritas. Orang-orang juga dapat menjadi selebritas karena perhatian media massa tertuju pada gaya hidup, kekayaan, atau tindakan kontroversial seseorang, atau karena hubungannya dengan orang yang lebih dahulu terkenal. 
Dalam media Tiktok juga memiliki beberapa selebritas ternama yang sering diikuti oleh para followers untuk melihat konten - konten yang mereka ciptakan sebagai hiburan. Pencarian hiburan ini tidak terlepas dari kebiasaan masyarakat Indonesia yang suka melihat sesuatu yang menarik dan juga viral. Sehingga, Aplikasi Tik Tok saat ini lebih banyak digunakan sebagai ajang untuk memamerkan diri atau yang sekarang biasa disebut eksistensi diri. Ada juga mengikuti kegiatan para selebritas serta sampai menjadi motivasi dan sumber inspirasi bagi pengikutnya. Terdapat akun Tiktok follower terbanyak Di indonesia, diantaranya :

- Sandy S.S.

- Cahyanirynn

- Ria Ricis

- Harna Bhagwani

- Saalhaerid

Berdasarkan hal - hal tersebut, penulis memiliki minat untuk menganalisis following to followers ratio Tiktok pada 5 artis Tiktok dengan followers terbanyak. Dalam mengetahui kredibilitas performa dari akun Tiktok follower terbanyak di Indonesia menggunakan Following To Followers Ratio.

Tujuan penulisan ini untuk menganalisis following to followers ratio Tiktok pada 5 artis Tiktok dengan followers terbanyak dalam kredibilitas performanya. Manfaat penulisan ini mengetahui seberapa baiknya performa dari para artis Tiktok dengan followers terbanyak.

\section{TINJAUAN PUSTAKA}

Perkembangan bidang teknologi saat ini terjadi begitu pesat. Melalui perkembangan yang terjadi dari waktu ke waktu menimbulkan maraknya aplikasi - aplikasi serta platform media sosial yang bermunculan. Aplikasi yang sangat diminati oleh masyarakat saat ini diantaranya adalah TikTok, Instagram, Twitter, WhatsApp dan yang lain sebagainya. Seiring berjalannya waktu, aplikasi sosial media tersebut dapat menjadi candu bagi kalangan masyarakat. Tidak hanya kalangan remaja yang menggunakan 
aplikasi sosial media, orang tua bahkan anak-anak juga aktif menggunakan aplikasi sosial media tersebut.

TikTok adalah salah satu platform media sosial yang perkembangannya paling cepat di dunia. TikTok memungkinkan penggunanya untuk membuat video pendek berdurasi 15 detik disertai musik, filter, dan beberapa fitur kreatif lainnya._Hampir 4 tahun setelah diluncurkan, TikTok mengalami ledakan popularitas. Pada akhir 2019, tercatat terdapat 500 juta pengguna aktif di seluruh dunia. Aplikasi ini juga digandrungi oleh berbagai kalangan di Indonesia, termasuk figur publik. Namun, tidak banyak orang mengetahui asal mula kehadiran TikTok yang telah menjadi candu ini. Mari simak sejarah perkembangan TikTok, dari awal kemunculannya sampai puncak kepopulerannya saat ini. (Martono \& Budiarjo, 2021)

Tiktok dibuat untuk menjadi media kreativitas anak muda yang ingin menjadi bagian dari revolusi konten. Tapi, banyak juga kalangan anak muda yang menggunakan Tiktok untuk konten negatif. Banyak anak muda yang berpakaian tidak sopan dan sampai melecehkan simbol agama. Fenomena Tiktok di kalangan anak muda ini seharusnya sudah menjadi perhatian bagi orang tua. Anak-anak muda menjadi tidak peduli atau lupa akan pengawasan Allah. Apalagi saat seperti ini, di masa pandemi, pasti kalangan remaja sering melupakan kewajibannya hanya untuk konten Tiktok. Tiktok sebenarnya positif jika digunakan sebagai ajang untuk berkreasi, berimajinasi, atau memperluas jaringan pertemanan(Nurul laila 2020, 2020)

TikTok dirasakan memiliki kekuatan ataupun pengaruh dalam industri, sehingga menimbulkan kualitas akun yang menentukan strata maupun kredibilitas pemilik akun. Kredibilitas akun TikTok merupakan suatu hal yang cukup penting untuk berbagai kepentingan. Kredibilitas sebuah akun TikTok dapat diukur dari tingkat performa yang dihasilkan secara matematis. Dalam mengukur performa diperlukan skala pengukuran yang tertuang ke dalam rasio. 


\section{METODE PENELITIAN}

Penelitian ini menggunakan metode eksploratif kuantitatif untuk mengetahui kredibilitas dari performa akun TikTok 5 Artis Tiktok Dengan Followers Terbanyak. Metode eksploratif merupakan penelitian yang memiliki tujuan untuk melakukan eksplorasi atau memperdalam pengetahuan ataupun ide-ide baru mengenai suatu hal yang baru, guna merumuskan permasalahan secara terperinci (Maryam \& Aeni, 2016).

Tujuan dari penelitian ini yaitu mengetahui nilai kredibillitas dari performa akun TikTok 5 Artis Tiktok Dengan Followers Terbanyak. Ada beberapa langkah yang harus dilakukan dalam penelitian ini, sehingga mampu menemukan peringkat pertama akun TikTok Followers Terbanyak

Artis Tiktok Followers Terbanyak yang memiliki performa terbaik. Langkah-langkah yang dilakukan

Pada penelitian ini, diantaranya yaitu :

\section{Menghitung Nilai Hasil Dari Top 5 Artis Tiktok Dengan Followers} Terbanyak.

Pada langkah ini, peneliti menghitung nilai Variabel Hasil Following To Followers. Variabel Yaitu Untuk menghitung nilai hasil dari variabel Following To Followers yaitu dengan cara mengambil Angka Pengikut dan Mengikuti kemudian Di hasilkan Followers Siapa yang paling Terbanyak Di Indonesia. 


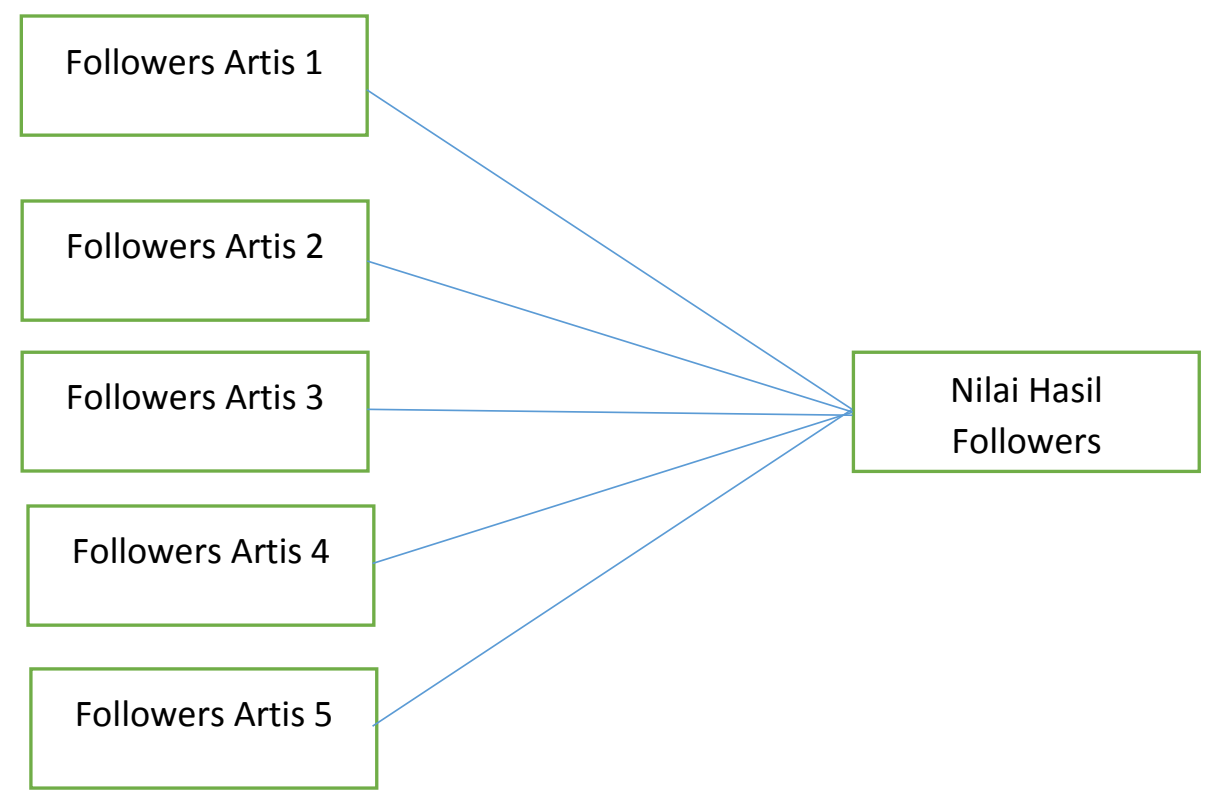

\section{Menghitung Nilai Kredibilitas Rasio}

Untuk menghitung nilai kredibilitas dari Following To Followers ratio, peneliti menggunakan cara membagi nilai variabel pertama dengan nilai variabel kedua. Jika Following memiliki nilai 400 dan Followers memiliki nilai 300, maka cara menghitungnya yaitu $400: 300=1,3$. Dengan begitu nilai dari Following To Followers ratio adalah 0,1.

\section{Menentukan Peringkat Pada Akun TikTok}

Pada langkah terakhir yang dilakukan pada penelitian ini yaitu menentukan peringkat pada masing-masing rasio yang ada. Pada penentuan peringkat perlu melihat karakteristik dari rasio yang di teliti. Jika karakteristik rasio merupakan rendah, maka objek yang memiliki nilai terendah akan mendapatkan angka 5 dan objek yang memiliki nilai tertinggi akan mendapatkan angka 1. Namun jika rasio memiliki karakteritik tinggi maka objek yang mendapatkan nilai tinggi akan mendapatkan angka 5 dan objek yang mendapatkan nilai terendah akan mendapatkan angka 1. Setelah mendapatkan hasil kredibilitas ratio maka dapat disimpulkan objek yang mana mendapatkan peringkat 1 sampai dengan peringkat 5. 


\title{
4. HASIL DAN PEMBAHASAN
}

Akun Tiktok Dengan Followers terbanyak Di indonesia, diantaranya :

1. Sandy.ss

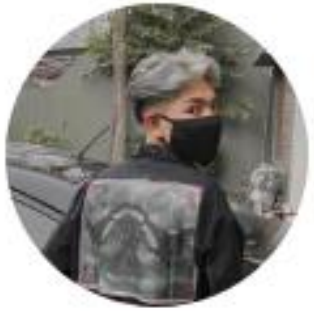

290 Following

IG "sandys.ss"

\section{sandys.ss}

ss

\section{Follow}

15.2M Followers $\quad 466.7 \mathrm{M}$ Likes

Sumber : https://www.tiktok.com/@sandys.ss? (Akses pada 22-10-2021)

\section{Cahyanirynn}

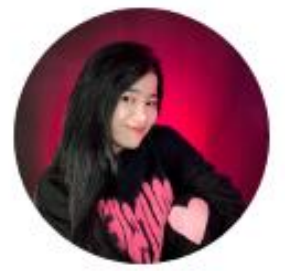

\section{cahyanirynn}

Cahyaniryn

\section{Follow}

\author{
203 Following $16.3 \mathrm{M}$ Followers $869.5 \mathrm{M}$ Likes \\ Brand Ambassador@teamrrq \\ Follow igku:cahyanirynt untuk keseharianku] \\ $\mathcal{N}$ s.nimo.tv/Nwpeove
}

Sumber : https://www.tiktok.com/@ cahyanirynn? (Akses pada 22-10-2021)

\section{Ria Ricis}

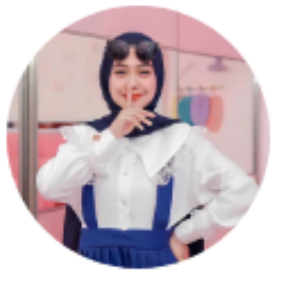

\section{riaricis}

Ria Ricis

\section{Follow}

1 Following 21.4M Followers 548M Likes

Ricismanagement@gmail.com

Sumber : https://www.tiktok.com/@ riaricis? (Akses pada 22-10-2021) 


\section{Jharnabhagwani}

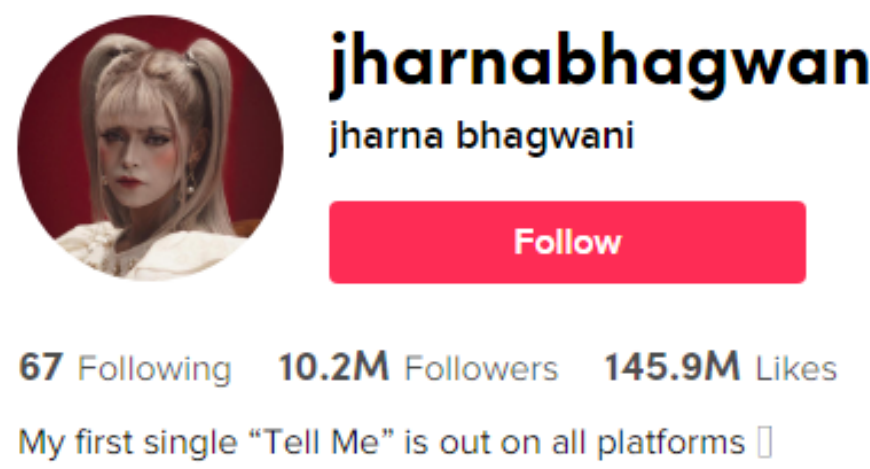

Sumber : https://www.tiktok.com/@jharnabhagwani? (Akses pada 22-10-2021)

\section{Saalhaerid}

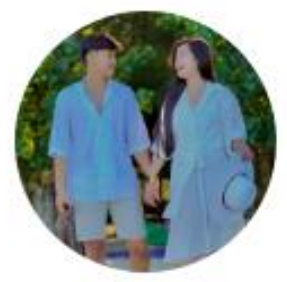

\section{saalhaerid}

\section{Said}
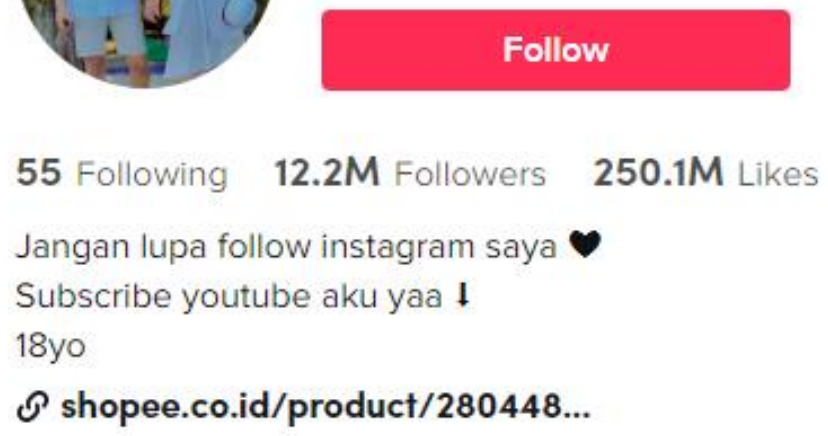

Sumber : https://www.tiktok.com/@ saalhaerid? (Akses pada 22-10-2021)

Dari kelima akun tersebut, peneliti menemukan nilai dari masing-masing variabel yang ada untuk menghitung rasio Following To Follower dari setiap akun. Berikut merupakan tabel nilai Hasil Following To Follower dari masing-masing Follower Terbanyak Di Indonesia, yaitu : 
Tabel 1. Analisis Nilai Hasil Following To Follower Akun Tiktok Pada kelima akun tiktok terbanyak di Indonesia

\begin{tabular}{|c|c|c|c|}
\hline NO & Artis Tiktok & Following & Followers \\
\hline 1 & Sandys.ss & 290 & $15,200,000$ \\
\hline 2 & Cahyanirynn & 202 & $16,200,000$ \\
\hline 3 & Ria Ricis & 1 & $21,100,000$ \\
\hline 4 & Jharna Bhagwani & 67 & $10,200,000$ \\
\hline 5 & Saalhaerid & 54 & $12,200,000$ \\
\hline
\end{tabular}

Sumber : Pengolahan Data

Tabel 2. . Hasil Rasio Akun Tiktok

\begin{tabular}{|c|c|c|c|c|c|}
\hline \multicolumn{7}{|c|}{ Tabel Ratio } \\
\hline Ratio & Sandys.ss & Cahyanirynn & Ria Ricis & $\begin{array}{c}\text { harna } \\
\text { Bhagwani }\end{array}$ & Saalhaerid \\
\hline $\begin{array}{c}\text { Following to } \\
\text { Followers }\end{array}$ & 0.0000190789 & 0.0000124691 & 0.0000000474 & 0.0000065686 & 0.0000044262 \\
\hline
\end{tabular}

Sumber : Pengolahan Data

Following To Follower Ratio memiliki karakteristik yang tinggi, artinya semakin tinggi nilai yang dihasilkan maka semakin baik kredibilitas dari performa akun tersebut. Untuk memberikan peringkat pada masing-masing akun Tiktok, peneliti memberikan angka 5 kepada Akun yang mendapatkan nilai tertinggi dan angka 1 untuk akun Tiktok yang mendapatkan nilai terendah. Berikut merupakan tabel urutan nilai yang dihasilkan oleh masing-masing akun Tiktok.

Tabel 3.. Nilai Rasio Akun Tiktok Follower Terbanyak Di Indonesia

\begin{tabular}{|c|c|}
\hline \multicolumn{2}{|c|}{ TABEL PERINGKAT } \\
\hline VARIABLE & Following to Followers \\
\hline Sandys.ss & 3 \\
\hline Cahyanirynn & 2 \\
\hline Ria Ricis & 1 \\
\hline Harna Bhagwani & 5 \\
\hline Saalhaerid & 4 \\
\hline
\end{tabular}

Sumber : Pengolahan Data

Dari Tabel Nilai dari tabel nilai di atas dapat simpulkan bahwa Harna Bhagwani mendapatkan nilai tertinggi untuk rasio Following To Follower . Sedangkan akun Tiktok Ria Ricis mendapatkan nilai terendah untuk rasio ini. Jadi, pada penelitian ini Harna Bhagwani memiliki kredibilitas performa yang lebih baik dibandingkan dengan Akun Tiktok yang lainnya. 


\section{KESIMPULAN}

Tujuan dari penelitian ini adalah mengetahui kredibilitas performa dari Akun Tiktok Follower Terbanyak Di Indonesia menggunakan Following To Follower Ratio. 5 Tiktok Terbanyak di Indonesia tersebut diantaranya : Sandys.ss, Cahyanirynn, Ria Ricis, Jharna Bhagwani,Saalhaerid. Dari kelima Artis Tiktok tersebut dapat disimpulkan bahwa :

1. Peringkat pertama diraih oleh Ria Ricis dengan nilai tertinggi yaitu 0.0000000474

2. Peringkat kedua diraih oleh Cahyanirynn dengan nilai 0.0000124691

3. Peringkat ketiga diraih oleh Sandys.ss dengan nilai 0.0000190789

4. Peringkat keempat diraih oleh Saalhaerid dengan nilai 0.0000044262

5. Peringkat kelima diraih oleh Harna Bhagwani dengan nilai terendah yaitu 0.0000065686

\section{DAFTAR PUSTAKA}

Martono, S., \& Budiarjo, H. (2021). Analisis Efektivitas Iklan Lembaga Pendidikan Tinggi Melalui Media Sosial Tiktok Dengan Pendekatan. Sebatik, 25(1), 9-18.

https://doi.org/10.46984/sebatik.v25i1.1173

Maryam, S., \& Aeni, A. N. (2016). Pendekatan Eksploratif Untuk Meningkatkan Kemampuan Berpikir Kreatif Dan Disposisi Matematis. Jurnal Pena Ilmiah, 1(1), 231-240.

https://doi.org/10.23819/pi.v1i1.3001

No Title $\square \square \square \square \square \square \square$. (n.d.). 1-25.

Nurul laila 2020. (2020). No Title. Fenomena Tiktok Di Kalangan Remaja. 
